\title{
Cloud condensation nuclei as a modulator of ice processes in Arctic mixed-phase clouds
}

\author{
S. Lance ${ }^{1,2}$, M. D. Shupe ${ }^{2,3}$, G. Feingold ${ }^{1}$, C. A. Brock ${ }^{1}$, J. Cozic ${ }^{1,2}$, J. S. Holloway ${ }^{1,2}$, R. H. Moore ${ }^{4}$, A. Nenes ${ }^{4,5}$, \\ J. P. Schwarz ${ }^{1,2}$, J. R. Spackman ${ }^{1,2}$, K. D. Froyd ${ }^{1,2}$, D. M. Murphy ${ }^{1}$, J. Brioude ${ }^{1,2}$, O. R. Cooper ${ }^{1,2}$, A. Stohl ${ }^{6}$, and \\ J. F. Burkhart ${ }^{6,7}$ \\ ${ }^{1}$ Chemical Sciences Division, Earth System Research Laboratory, National Oceanic and Atmospheric Administration, \\ Boulder, CO, USA \\ ${ }^{2}$ Cooperative Institute for Research in Environmental Sciences, University of Colorado, Boulder, CO, USA \\ ${ }^{3}$ Physical Sciences Division, Earth System Research Laboratory, National Oceanic and Atmospheric Administration, \\ Boulder, CO, USA \\ ${ }^{4}$ School of Chemical \& Biomolecular Engineering, Georgia Institute of Technology, Atlanta, GA, USA \\ ${ }^{5}$ School of Earth and Atmospheric Sciences, Georgia Institute of Technology, Atlanta, GA, USA \\ ${ }^{6}$ Norwegian Institute for Air Research, Kjeller, Norway \\ ${ }^{7}$ Sierra Nevada Research Institute, University of California, Merced, CA, USA
}

Received: 25 January 2011 - Published in Atmos. Chem. Phys. Discuss.: 25 February 2011

Revised: 26 July 2011 - Accepted: 27 July 2011 - Published: 5 August 2011

\begin{abstract}
We propose that cloud condensation nuclei (CCN) concentrations are important for modulating ice formation of Arctic mixed-phase clouds, through modification of the droplet size distribution. Aircraft observations from the Aerosol, Radiation, and Cloud Processes affecting Arctic Climate (ARCPAC) study in northern Alaska in April 2008 allow for identification and characterization of both aerosol and trace gas pollutants, which are then compared with cloud microphysical properties. Consistent with previous studies, we find that the concentration of precipitating ice particles (> $400 \mu \mathrm{m})$ is correlated with the concentration of large droplets $(>30 \mu \mathrm{m})$. We are further able to link the observed microphysical conditions to aerosol pollution, originating mainly from long range transport of biomass burning emissions. The case studies demonstrate that polluted mixed-phase clouds have narrower droplet size distributions and contain 1-2 orders of magnitude fewer precipitating ice particles than clean clouds at the same temperature. This suggests an aerosol indirect effect leading to greater cloud lifetime, greater cloud emissivity, and reduced precipitation. This result is opposite to the glaciation indirect effect, whereby polluted clouds are expected to precipitate more readily due to an increase in the concentration of particles acting as ice nuclei.
\end{abstract}

\section{Correspondence to: S. Lance}

(sara.m.lance@noaa.gov)

\section{Introduction}

Understanding the effect of aerosol on mixed-phase cloud radiative forcing may be critical for understanding climate change in the Arctic. Aerosols can indirectly cool the Earth's surface by increasing the shortwave scattering of incident solar radiation through an increase in cloud reflectivity, coverage or lifetime (Twomey, 1974; Albrecht, 1989). Aerosols can also increase cloud longwave emissivity when liquid water path is low, which can warm the Earth's surface (Garrett et al., 2002; Lubin and Vogelmann, 2006). The Arctic is potentially sensitive to this longwave aerosol effect, since low altitude clouds are often warmer than the underlying snow and ice covered surfaces (Garrett et al., 2002) and since clouds with liquid water path $<100 \mathrm{~g} \mathrm{~m}^{-2}$ are common in the Arctic.

Low-level boundary layer clouds are persistent in the Arctic for all seasons (Curry et al., 1996; Shupe et al., 2011). An important characteristic of these clouds during winter and spring is that they are frequently mixed-phase, with supercooled liquid water droplets and ice particles often coexisting for several hours to many days (Shupe et al., 2006, 2011), with a lifetime that is thought to depend on the cooling rate, concentration and type of ice nuclei (IN) present (e.g. Pinto, 1998; Intrieri et al., 2002; Korolev and Isaac, 2003; Morrison et al., 2005). Cloud-resolving model studies have shown that by increasing IN number concentration by $2-3$ times, a liquid

Published by Copernicus Publications on behalf of the European Geosciences Union. 
stratus deck can be transformed into a broken, optically-thin ice cloud system (Harrington et al., 1999; Jiang et al., 2000; Harrington and Olsson, 2001) due to the Wegener-BergeronFindeisen process (Wegener, 1911; Bergeron, 1935; Findeisen, 1938). The resulting ice cloud has a much lower particle number density; these sparse, relatively large ice crystals reduce the cloud optical depth (thereby reducing the cloud's radiative effects), and settle relatively rapidly (thereby reducing the cloud lifetime).

During the springtime, pollution is often transported from lower latitudes to the Arctic, leading to what is known as "Arctic haze" (Shaw, 1975; Rahn et al., 1977; Lubin and Vogelmann, 2006; Quinn et al., 2007; Garrett et al., 2010). The persistent temperature inversions that develop during this time period in the lower Arctic troposphere inhibit vertical mixing, which can give rise to multiple layers of concentrated pollution plumes originating from long range transport of fossil fuel and biomass burning emissions (Radke et al., 1984; Warneke et al., 2010), which are superimposed on the seasonal background haze (Brock et al., 2010). Arctic haze has been correlated with an increase in the number concentration of supercooled liquid cloud droplets (resulting from an increase in $\mathrm{CCN}$ ) and a decrease in cloud droplet effective radii, which can together increase the cloud longwave emissivity (Lubin and Vogelmann, 2006). However, Arctic haze and concentrated pollution plumes can also be associated with elevated IN concentrations, which may increase the rate of cloud glaciation thereby reducing cloud longwave emissivity as well as cloud lifetime. Thus, the net effect of aerosol pollution on Arctic clouds remains unclear.

Previous studies have proposed different mechanisms for the influence of aerosols on cloud phase partitioning. Proposed mechanisms include: (1) the "glaciation indirect effect" (Lohmann, 2002), in which black carbon (soot) pollution provides more IN (acting predominantly in the contact nucleation mode), leading to a greater number of ice particles formed and enhancements in ice precipitation, (2) the "riming indirect effect", also known as "inhibition of snowfall by pollution aerosol" (Borys et al., 2003), in which pollution provides more $\mathrm{CCN}$, leading to smaller droplets that rime less effectively, thereby decreasing the mass of ice precipitation, (3) the "thermodynamic indirect effect" (Lohmann and Feichter, 2005), in which pollution provides more CCN, leading to smaller droplets that freeze less readily. This last effect has been invoked to explain observed correlation between large droplet and ice crystal concentrations in slightly to moderately supercooled clouds (Hobbs and Rangno, 1985; Korolev et al., 2003), although the dominant freezing mechanism(s) taking place are not universally agreed upon.

In this paper we present observations of polluted and clean clouds from the ARCPAC study (http://www.esrl.noaa.gov/ csd/arcpac/) in northern Alaska April 2008. These observations provide evidence that $\mathrm{CCN}$ concentrations rather than IN concentrations are the primary limiting factor for ice formation in these slightly to moderately supercooled mixed-phase clouds ( -4 to $-20^{\circ} \mathrm{C}$, as defined by Rangno and Hobbs, 2001), as a result of modifications to the droplet size distribution.

\section{Methods}

\subsection{Instrumentation}

The instrument payload during ARCPAC is unique for cloud microphysical studies. The NOAA WP-3D aircraft was extensively outfitted for trace gas measurements in addition to aerosol and cloud microphysical measurements, which allowed for identification and characterization of intercepted pollution plumes. Data from the ARCPAC campaign is available at http://www.esrl.noaa.gov/ csd/tropchem/2008ARCPAC/P3/DataDownload/. Measurements of biomass burning (BB) aerosol tracers, carbon monoxide $(\mathrm{CO})$, acetonitrile $\left(\mathrm{CH}_{3} \mathrm{CN}\right)$ and other volatile organic compounds, coupled with transport model simulations, provide for clear identification of plumes originating from biomass burning emissions in southern Russia and southeastern Siberia (Warneke et al., 2009). Trace gas and aerosol composition measurement techniques are outlined by Warneke et al. (2009) and Brock et al. (2010). Dry aerosol size distributions $\left(4 \mathrm{~nm}<\mathrm{d}_{\mathrm{p}}<8.3 \mu \mathrm{m}\right.$ ) were obtained from three separate instruments: a five-channel condensation particle counter, an ultra high sensitivity aerosol spectrometer and a white light optical counter (Brock et al., 2010). Single particle composition measurements (for dry particle diameters, $d_{p}>150 \mathrm{~nm}$ ) were obtained using the particle analysis by laser mass spectrometery (PALMS) instrument (Murphy et al., 2006). CCN measurements were obtained using a continuous flow streamwise thermal gradient chamber (Roberts and Nenes, 2005) built by Droplet Measurement Technologies (DMT) (Lance et al., 2006). A DMT single particle soot photometer (Schwarz et al., 2006) measured the refractory black carbon (BC) mass of single particles. A DMT cloud droplet probe (CDP), cloud imaging probe (CIP) and precipitation imaging probe (PIP) were used to measure cloud particle diameters spanning the range $3-6000 \mu \mathrm{m}$. Lance et al. (2010) describe in detail the performance of the CDP (3$50 \mu \mathrm{m})$ during ARCPAC. A King probe was used to measure liquid water content (LWC), and is corrected using the procedure outlined by King et al. (1978). LWC calculated based on the measured droplet size distribution is referred to as CDP-LWC, whereas measurements from the King probe are referred to as King-LWC or simply LWC.

\subsection{Phase determination and definition of a cloud}

Cloud particle concentrations are highly sensitive to the way a "cloud" is defined (Gultepe and Isaac, 1999). For every $1 \mathrm{~s}$ sampling interval during the ARCPAC flights, the following criteria are used to identify a cloud: $>10 \mathrm{~cm}^{-3}$ droplets (with diameter $3-50 \mu \mathrm{m}$, as measured by the CDP), 
Or $>0.01-0.02 \mathrm{~L}^{-1}$ ice particles (with diameter $>400 \mu \mathrm{m}$, as measured by the PIP)

The first criterion is essentially the same as that used by Hobbs and Rangno (1998) for mixed-phase clouds, whereas the second criterion is modified to reflect new information that has been discovered about ice shattering artifacts; Korolev et al. (2011) showed that measured concentrations for ice particles with diameter $>\sim 400 \mu \mathrm{m}$ are much less susceptible to shattering artifacts than concentrations measured in the range $100-400 \mu \mathrm{m}$, which were included in the criterion used by Hobbs and Rangno (1998). Phase identification based on CIP and PIP images is also much more reliable when the particle diameter is $>400 \mu \mathrm{m}$. However, ice concentrations at $400 \mu \mathrm{m}$ are typically $\sim 2$ orders of magnitude lower than concentrations at $100 \mu \mathrm{m}$. We therefore use a threshold concentration for the second criterion that is approximately two orders of magnitude lower than that used by Hobbs and Rangno (1998). Because this lower concentration cutoff approaches the counting limits of the PIP, our second criterion is chosen to limit concentration uncertainty due to counting statistics to $<50 \%$ for particles $>400 \mu \mathrm{m}$. The range of concentrations for this second criterion is a result of the fact that the sample area for PIP measurements, and therefore the concentration uncertainty, is dependent on the particle size. The second criterion will not be appropriate for all cloud types (e.g., colder free tropospheric clouds where ice crystals do not grow to diameters $>400 \mu \mathrm{m}$ ).

Ice water content (IWC) is estimated from the measured size distribution using the parameterization by Mitchell et al. (1990),

$\mathrm{IWC}=\mathrm{C} \sum n_{i} D_{i}^{2}$

where $\mathrm{C}=0.022 \mathrm{mg} \mathrm{mm}^{-2}$ and $n_{\mathrm{i}}$ is the ice number concentration for particles with maximum linear dimension $D_{\mathrm{i}}$. Lawson and Baker (2006) show that this parameterization may underestimate IWC by more than a factor of two for the Arctic stratus that they analyzed. However, even given the possibility of such a large underestimate of IWC, it is clear that the mixed-phase clouds sampled during ARCPAC were dominated by liquid water. In mixed-phase clouds, IWC estimated using the Mitchell et al. (1990) parameterization was almost always $<0.01 \mathrm{~g} \mathrm{~m}^{-3}$ and almost never $>0.1 \mathrm{~g} \mathrm{~m}^{-3}$, whereas LWC often exceeded $0.1 \mathrm{~g} \mathrm{~m}^{-3}$. When IWC $>0.01 \mathrm{~g} \mathrm{~m}^{-3}$, King-LWC measurements were biased by up to $0.08 \mathrm{~g} \mathrm{~m}^{-3}$, which is greater than expected from previous studies (e.g., Cober et al. 2001). The apparently greater sensitivity of the King-LWC measurement to icing during ARCPAC may be due to an underestimate in IWC for the dendrite aggregates that were sampled at the highest IWC observed.

\subsection{Case studies}

For this paper, we have focused on the 19 April 2008 flight (lasting until 20 April when all measurements discussed in this paper were made), which had the greatest dynamic range of in-cloud $\mathrm{CO}$ concentrations and also the longest duration of in-cloud sampling of any of the ARCPAC flights. Figure $1 \mathrm{~b}$ shows a timeseries of $\mathrm{CO}$ concentrations and cloud particle size distributions for this flight. From these observations we identify three periods, highlighted in Fig. 1b, based on their $\mathrm{CO}$ concentrations and cloud-top temperatures. The three case studies, which we discuss throughout the rest of this paper, are:

1. "Warm-Polluted": $\mathrm{CO}>200$ ppbv, cloud top minimum temperature $\sim-10^{\circ} \mathrm{C}$

2. "Clean": CO $\sim 160 \mathrm{ppbv}$ (background mixing ratio for this season in the Arctic, as shown by Brock et al. (2010)), cloud top minimum temperature $\sim-14^{\circ} \mathrm{C}$

3. "Polluted": CO > 200 ppbv, cloud top minimum temperature $\sim-15^{\circ} \mathrm{C}$

To isolate cloud-aerosol interactions, ideally only cases with the same cloud-top temperatures would be compared to one another (such as the clean and polluted cases). However, the total sampling time in the polluted cloud was only a few minutes (Fig. 1b). We present the warm-polluted case as a comparison, with at least $30 \mathrm{~min}$ of in-cloud sampling and with many consistent features to the polluted case, as discussed in Sect. 3.2.

The measured cloud particle size distributions (Fig. 1b) are derived from three separate instruments, with the CDP covering the range $3-50 \mu \mathrm{m}$, the CIP covering the range 50$200 \mu \mathrm{m}$, and the PIP covering the range $200-6000 \mu \mathrm{m}$. The number concentrations, indicated by color, are reported as $\mathrm{dN} / \mathrm{d} \log \mathrm{D}_{\mathrm{p}}$ to allow for direct comparison across different particle size ranges, and are plotted on a log scale to capture the full range of concentrations. Each instrument has different sample volumes, which results in different lower counting limits. White space in the size distribution indicates concentrations below the ability of a given instrument to measure. Figure 1a shows the 19 April 2008 flight track, over Barrow, Alaska $\left(71^{\circ} 17^{\prime} 44^{\prime \prime} \mathrm{N} 156^{\circ} 45^{\prime} 59^{\prime \prime} \mathrm{W}\right)$, and then later north of Barrow over the Arctic sea ice. Droplet concentrations corrected for coincidence errors (Lance et al., 2010) are also shown in Fig. 1a for clouds with droplet concentrations $>10 \mathrm{~cm}^{-3}$.

\subsection{Simulated transport}

The FLEXPART Lagrangian particle dispersion model (Stohl et al., 2005) was used to characterize the transport of pollution into the Alaskan Arctic region from surface emissions. From each location along the NOAA WP-3D flight tracks, 20-day retroplumes were calculated. The model output (reported as $\mathrm{ns} \mathrm{kg}^{-1}$ ) is proportional to the residence time of the particles in a given volume of air and corresponds to an emission sensitivity. When convolved with the gridded emission fluxes from an emission inventory and integrated 


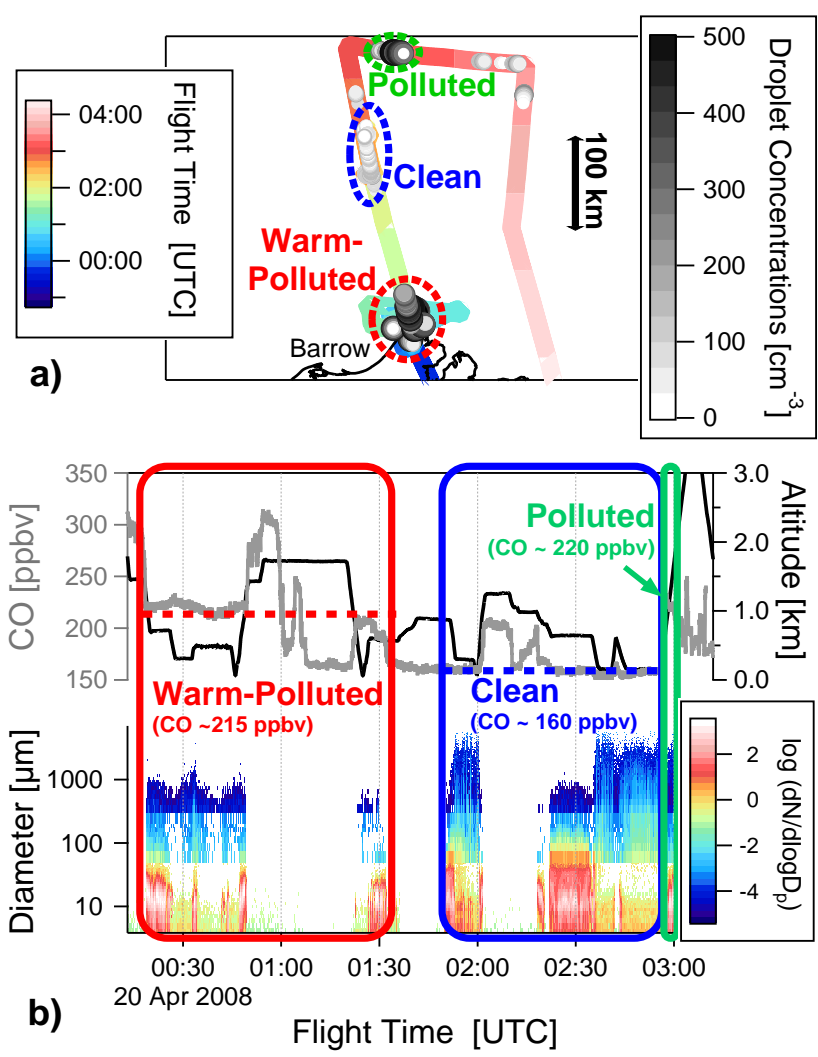

Fig. 1. (a) Flight track on 19 April 2008 colored by time, with cloud droplet concentrations marked in greyscale. (b) Timeseries of carbon monoxide concentrations (top) and cloud particle size distributions (bottom) on the 19 April 2008 ARCPAC flight. The three cases as described in Sect. 2.3 are highlighed: warm-polluted clouds (red), clean clouds (blue), and polluted clouds (green).

over the volume of the atmosphere, a model-calculated mixing ratio of the emitted species at the location of the aircraft is obtained. EDGAR fast track 2000 (Olivier and Berdowski, 2001) was used as the anthropogenic emissions inventory, and for biomass burning the inventory was based on fire locations detected by the moderate resolution imaging spectroradiometer (MODIS, NASA/University of Maryland, 2002) onboard the Terra and Aqua satellites and a land cover classification (Stohl et al., 2007). The model was run with both GFS $\left(0.5^{\circ} \times 0.5^{\circ}\right.$ horizontal resolution, 26 vertical levels $)$ and ECMWF $\left(1^{\circ} \times 1^{\circ}\right.$ horizontal resolution, 90 vertical levels) global meteorological fields.

The modeled transport pathways of the clean and polluted air masses were verified against satellite imagery and in situ measurements. Retroplumes calculated from both GFS and ECMWF wind fields were used. Both wind fields produced a similar transport pathway for the warm-polluted case, but differed for the clean and polluted cases, with differences likely resulting from the different vertical resolutions of the models. Comparison of modeled and measured $\mathrm{CO}$ mixing ratios showed that the GFS winds produced a transport pathway consistent with the clean air mass while the ECMWF wind fields produced a transport pathway consistent with the polluted air mass. This blend of model output is used in the following description of the transport processes (see Supplement, Fig. S1-S3).

The retroplumes indicate that the warm-polluted and polluted air masses accumulated smoke from biomass burning in Asia, first from agricultural burning in Kazakhstan and southern Russia, and then from boreal forest fires between Lake Baikal and the coast of southeastern Siberia (Warneke et al., 2009). These emissions mainly occurred during 10-15 April, with a greater contribution from the fires in southeastern Siberia. The smoke was subsequently advected off the coast of southeastern Siberia, across northern Japan and became entrained into the post cold front airstream of a midlatitude cyclone forming just east of Japan. Over the next 3 days the air masses descended and then ascended slightly as they traveled northwards coming close to the center of the cyclone where low-level stratus clouds formed by the early hours of 18 April. The FLEXPART trajectories and the satellite images suggest that the warm-polluted and polluted air masses were probably influenced by clouds during the $48 \mathrm{~h}$ prior to the time they were sampled by the NOAA WP-3D.

Although the FLEXPART retroplumes indicate an Asian origin for the clean air mass, it did not receive strong emissions from biomass burning or anthropogenic sources on those days. The clean air mass took a different path to the Arctic traveling at low altitude under the warm conveyor belt of the cyclone and wrapping around the center of the low just prior to the time it was sampled by the WP-3D. Because the high level clouds of the warm conveyor belt obscure the view of the lower troposphere we cannot estimate the length of time that the air mass was influenced by clouds.

\section{Results}

\subsection{Aerosol characterization}

A fundamental challenge for cloud-aerosol interaction studies is characterizing the aerosol that has initiated cloud formation. In-cloud measurements of aerosol are difficult to interpret, especially in mixed-phase conditions. To address this problem, we utilize trace gas observations, such as carbon monoxide ( $\mathrm{CO}$ ) and acetonitrile, for which the measurement technique and the ambient gas are unaffected by clouds.

\subsubsection{Cloud condensation nuclei}

A strong correlation was observed between $\mathrm{CO}$ and $\mathrm{CCN}$ concentrations at low water vapor supersaturations $(<0.125 \%)$ in clear air on the 19 April 2008 flight (Fig. 2a). We take advantage of this correlation in clear air to estimate the concentration of $\mathrm{CCN}$ upon which clouds have formed. Observed in-cloud $\mathrm{CO}$ concentrations are therefore used as a proxy for CCN. For qualitative evidence in support 


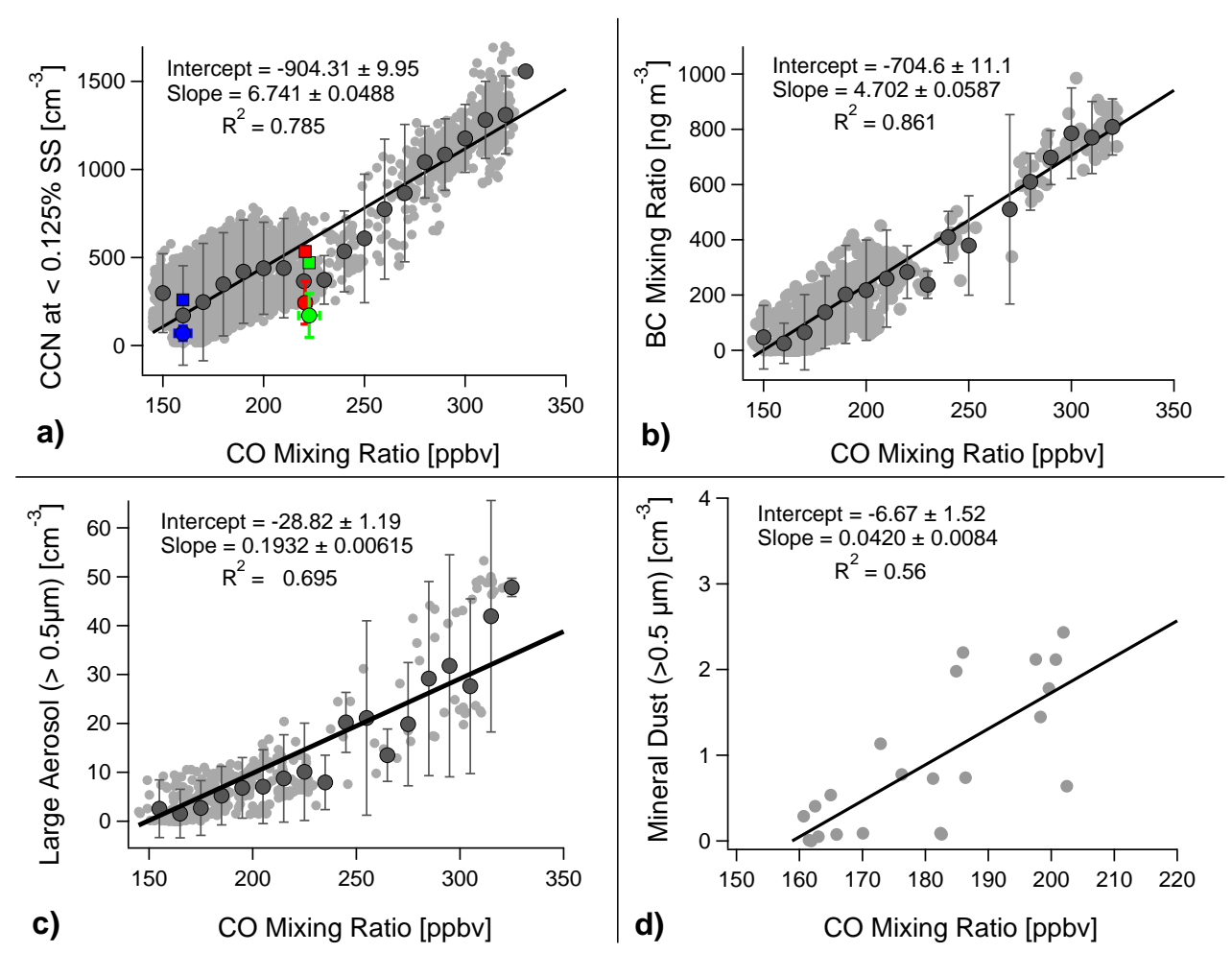

Fig. 2. (a) Cloud Condensation Nuclei (CCN), (b) black carbon (BC), (c)) large aerosol, and (d) mineral dust concentrations as a function of carbon monoxide (CO) mixing ratios in clear air during the 19 April 2008 flight. Average (circles) and maximum (squares) measured cloud droplet concentrations for the 3 cases introduced in Fig. 1 are also plotted in Fig. 2a. In polluted conditions (i.e. higher CO), both more CCN and more IN are expected.

of this assumption, regions of higher droplet concentrations (Fig. 1a) correspond to polluted airmasses, as identified by higher $\mathrm{CO}$ concentrations (Fig. 1b). In Fig. 2a, average and maximum droplet concentrations are directly compared to $\mathrm{CCN}$ concentrations for the three different case studies. The maximum droplet concentrations are consistent with the average $\mathrm{CCN}$ concentrations observed in clear air at a given $\mathrm{CO}$ concentration. However, since water vapor supersaturations are not known for these mixed-phase clouds, direct comparison between $\mathrm{CCN}$ and droplet concentrations is not fully constrained. Supersaturations (relative to liquid water) in these weakly convective Arctic mixed-phase stratus are expected to be quite close to saturation (Korolev and Mazin, 2003), therefore we use CCN concentrations measured at the lowest instrument supersaturation $(<0.125 \%)$ in our analysis. The relationship between $\mathrm{CO}$ and $\mathrm{CCN}$ concentrations at higher supersaturations exhibits more variability, likely due to greater variability in aerosol particle concentrations at smaller sizes, but nevertheless exhibits a similar trend (not shown). The difference between the average droplet concentrations and average $\mathrm{CCN}$ concentrations could be a result of cloud supersaturations $<0.125 \%$ or due to cloud processes such as collision coalescence, evaporation, dilution or riming, which act to lower droplet concentrations.

\subsubsection{Ice nuclei}

Measurements of IN were not obtained on board the NOAA WP-3D during the ARCPAC study. However, several different measurements of aerosol composition and particle size were obtained, which are relevant for the ice nucleation efficiency of aerosols.

Many studies have shown that ice nucleation efficiency is highly sensitive to aerosol particle size (e.g., Pruppacher and Klett, 2000). By accounting for both particle size and temperature, ice nuclei can sometimes be predicted to within at least an order of magnitude, which is an improvement of approximately two orders of magnitude over using temperature alone (DeMott et al., 2010). On the 19 April 2008 ARCPAC flight, the concentration of large aerosol particles (with diameter $>0.5 \mu \mathrm{m}$ ) was strongly correlated with CO concentrations (Fig. 2c). Thus, we expect based on the size distribution of the particles alone that the polluted conditions contain more IN.

However, aerosol compositional differences may lead to significant differences in the ice forming potential of the aerosols. For instance, the glaciation indirect effect was specifically formulated on the assumption that soot particles act as contact IN. This model assumption was based on laboratory studies showing that oxidized soot from incomplete 


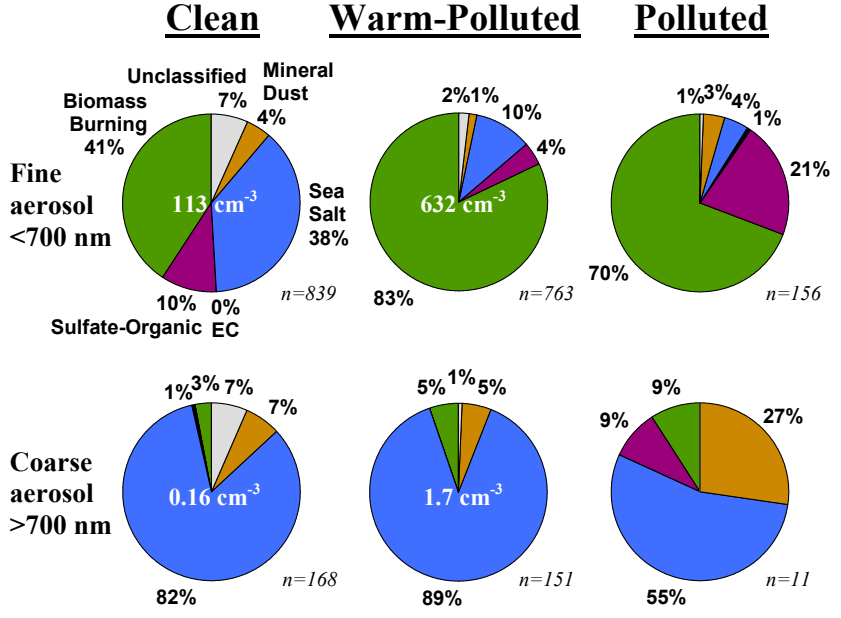

Fig. 3. Fraction of fine and coarse aerosol particle types identified by single particle mass spectrometry. Number concentrations inferred from the coarse aerosol size distributions are listed in white text. Also reported are the number of particles detected by the PALMS for each case $(n)$.

combustion initiates freezing upon contact with droplets even at fairly warm temperatures $\left(-5\right.$ to $-20^{\circ} \mathrm{C}$ ) (Gorbunov et al., 2001). Observations at the high mountain research laboratory at Jungfraujoch in Switzerland also showed that black carbon (BC) mass is enhanced in ice crystals relative to liquid droplets, suggesting that some $\mathrm{BC}$-containing particles may preferentially act as ice nuclei (Cozic et al., 2008). Mass concentrations of $\mathrm{BC}$ and $\mathrm{CO}$ mixing ratios in clear air were highly correlated on the 19 April 2008 flight (Fig. 2b). Thus, again we expect that the polluted conditions contain more IN.

Laboratory studies have shown that aerosol particles produced from biomass burning of certain plants (including some grasses, hardwood trees and softwood trees) can be efficient immersion IN at relatively cold temperatures of $-30^{\circ} \mathrm{C}$ (Petters et al., 2009). Biomass burning (BB) emission may include the relatively large ash particles produced as a result of the noncombustible mineral content of plants, as well as biological particles such as pollen and plant debris, bacteria or fungi, the most efficient natural IN known (von Blohn et al., 2005), which may be thermally lofted along with the biomass burning smoke (Reid et al., 1998). Single particle mass spectrometer observations made with the PALMS instrument show that fine mode $(150-700 \mathrm{~nm}) \mathrm{BB}$ particles are highly correlated with $\mathrm{CO}$ mixing-ratios (not shown). Both the fraction and number concentration of BB particles are higher in the polluted cases than in the clean case (Fig. 3).

Mineral dust is one of the most important IN due to a high ice nucleation efficiency and global abundance (Cantrell and Heymsfield, 2005; Phillips et al., 2008). Concentrations of mineral dust particles $>500 \mathrm{~nm}$ identified by PALMS and dry aerosol size distribution measurements were correlated with $\mathrm{CO}$ mixing ratios averaged over 5 minute intervals on the 19 April 2008 Flight (Fig. 2d). Coarse mode mineral dust concentrations were roughly $10 \mathrm{~L}^{-1}$ and $90 \mathrm{~L}^{-1}$ in the clean and polluted environments, respectively (Fig. 3). Thus, again we expect that IN concentrations are greater in the polluted cases than in the clean case. However, soluble organic or sulfate coatings can inhibit the ice nucleation efficiency of mineral dust particles (Möhler et al., 2008; Cziczo et al., 2009). The PALMS measurements indicate that in both the clean and polluted cases, the mineral dust particles are coated with organics. The mass of organic coating on the mineral dust particles increases as a function of $\mathrm{CO}$ mixing ratio (not shown), suggesting that a smaller fraction of the greater number of mineral dust particles might be acting as IN in the polluted cases, at least in the deposition freezing mode. Since these mineral dust particles are coated, they may act as IN from within droplets, as by immersion freezing or contact nucleation from inside-out (Durant and Shaw, 2005).

\subsection{Cloud microphysical properties}

In the clean case (Fig. 4a), there are several mixed-phase cloud layers, with a maximum concentration of ice precipitation $(>400 \mu \mathrm{m})$ below the lowest (and coldest) liquid cloud layer. Droplet concentrations are $<100 \mathrm{~cm}^{-3}$ on average, and ice precipitation concentrations are often $>1 \mathrm{~L}^{-1}$. This case is representative of Type $\mathrm{V}$ clouds identified by Rangno and Hobbs (2001): moderately supercooled stratiform clouds (cloud top -10 to $-20^{\circ} \mathrm{C}$ ) with droplets $>30 \mu \mathrm{m}$ at cloud top and droplet concentrations typically $<100 \mathrm{~cm}^{-3}$. Note that LWC for the clean case is $<0.2 \mathrm{~g} \mathrm{~m}^{-3}$, and images of the ice precipitation do not show significant riming. Because many of these precipitation particles are agglomerates of ice crystals, the IN concentration in the clean case may be even higher than the reported concentration of ice precipitation.

In contrast, for the warm-polluted case (Fig. 4b), the single layer cloud is thicker and attains a higher LWC at cloudtop, with a maximum LWC up to $0.6 \mathrm{~g} \mathrm{~m}^{-3}$. This case is more representative of Type I clouds described by Rangno and Hobbs (2001): slightly supercooled stratiform clouds (cloud top 0 to $-10^{\circ} \mathrm{C}$ ) with droplet concentrations typically $>100 \mathrm{~cm}^{-3}$, and very little ice precipitation. The hydrometeor images show more riming than in the clean case, but the LWC is also three times higher. Regardless of the mechanisms by which the degree of riming varies, the substantial riming observed at the temperature range of the warm-polluted case is conducive for secondary ice formation via the Hallett-Mossop mechanism (Mossop, 1985), and yet the ice precipitation concentrations average 1-2 orders of magnitude lower than in the clean case. Since the minimum temperature of the warm-polluted clouds is higher than in the clean case $\left(-10^{\circ} \mathrm{C}\right.$ instead of $\left.-14^{\circ} \mathrm{C}\right)$, however, a look into the polluted case provides a more direct comparison.

For the polluted case (Fig. 4c), measurements were obtained first by ascending through a clean cloud layer and then 

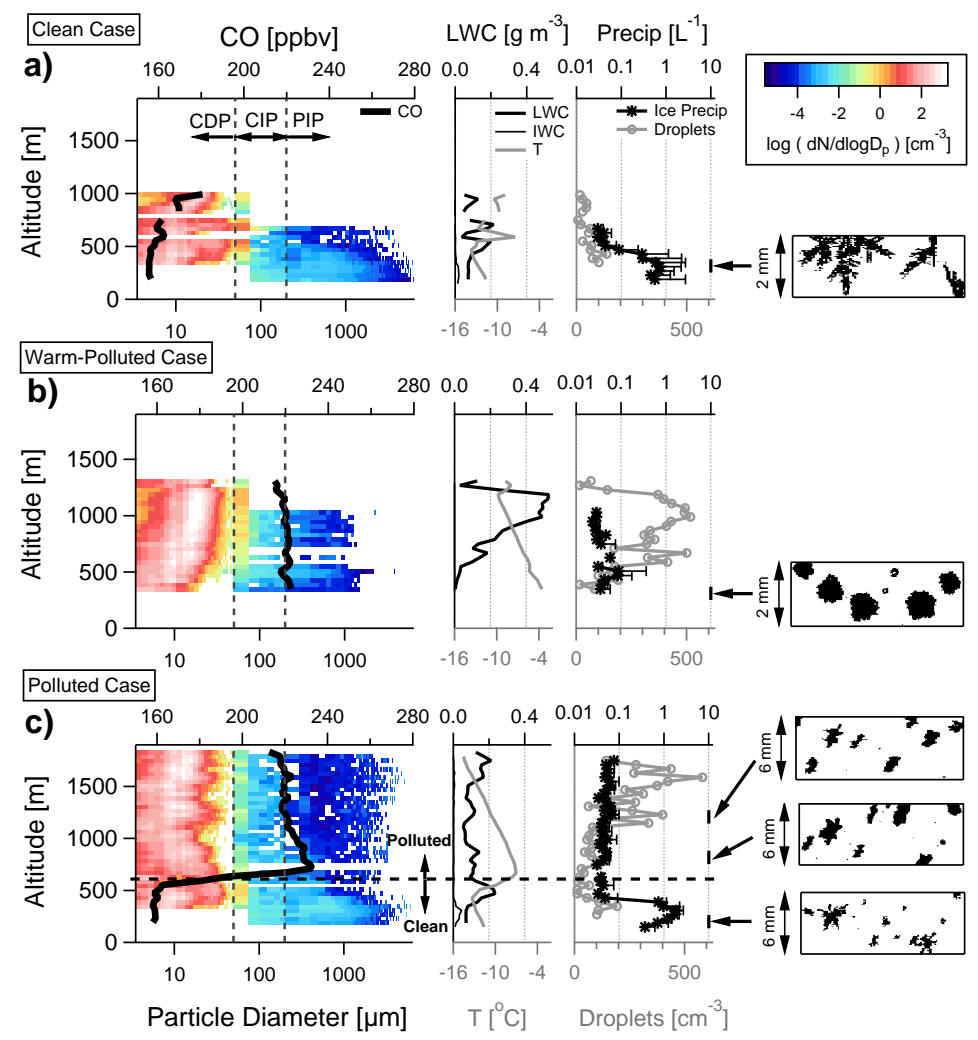

Fig. 4. Average cloud microphysical properties (cloud particle size distributions, as well as measured concentrations of droplets and ice precipitation $>400 \mu \mathrm{m}$ ), liquid water content (LWC), ice water content (IWC), temperature ( $T$ ) and Carbon Monoxide (CO), as a function of altitude for the three cases. White space in the size distributions (left) is due either to instrument counting limits (as in Fig. 1b) or due to the lower concentration cutoff for the definition of a cloud (Sect. 2.2). Also shown are images of ice precipitation from the CIP and PIP measurements, with arrows indicating the altitude where the images were observed.

through a much thicker polluted cloud layer (as clearly identified by a step change in CO concentrations at $\sim 600 \mathrm{~m}$ altitude. The polluted case is representative of Type IV clouds classified by Rangno and Hobbs (2001): moderately supercooled stratiform clouds (cloud top -10 to $-20^{\circ} \mathrm{C}$ ) with droplet concentrations $>100 \mathrm{~cm}^{-3}$, and little to no ice precipitation. The clean clouds at lower altitudes in this case again exhibit ice precipitation with 1-2 orders of magnitude greater concentrations than the polluted clouds, and many more large droplets $(>30 \mu \mathrm{m})$ as well.

We believe that the majority of the $\sim 30 \mu \mathrm{m}$ particles observed in the clean cases are liquid droplets, and not small ice crystals, due to the good agreement between the CDPLWC and King-LWC and the fact that these large droplets (although few in number) contribute a significant fraction of the LWC observed (Fig. 5). Furthermore, measurement of these large droplets is not strongly influenced by ice shattering artifacts, because the large droplets are observed at cloud-top where ice concentrations are relatively low, but are not observed where ice mass or number concentrations are greatest. This spatial separation increases our confidence in the cloud probe measurements, which can be subject to significant artifacts in mixed-phase clouds (Korolev et al., 2011; Cober et al., 2001). However, the spatial separation also means that $1 \mathrm{~Hz}$ measurements of large droplet concentration and high ice precipitation concentrations are not directly correlated, because these microphysical parameters are not vertically collocated (Fig. 4). Instead, we independently compare droplet and ice precipitation concentrations between the cases.

The concentration of large droplets increases as a function of LWC (Fig. 6a), but this trend is distinctly different for the clean and polluted cases, with a slope for the clean clouds of at least $14 \mathrm{~cm}^{-3}\left(\mathrm{~g} \mathrm{~m}^{-3}\right)^{-1}$ and a slope of only $1.4 \mathrm{~cm}^{-3}$ $\left(\mathrm{g} \mathrm{m}^{-3}\right)^{-1}$ for the polluted clouds. Significant concentrations of droplets $>30 \mu \mathrm{m}$ are a distinct feature observed only in the clean case (Fig. 6b), possibly due to a more active collision coalescence process. For both the clean case and the clean cloud at low altitude in the polluted case, the maximum in droplet volume mean diameter occurs near the altitude where ice precipitation begins (Fig. 4). The negative correlation between $\mathrm{CO}$ and the concentration of droplets $>30 \mu \mathrm{m}$ is an important feature in our dataset, providing evidence that pollution is driving observed cloud microphysical differences. 


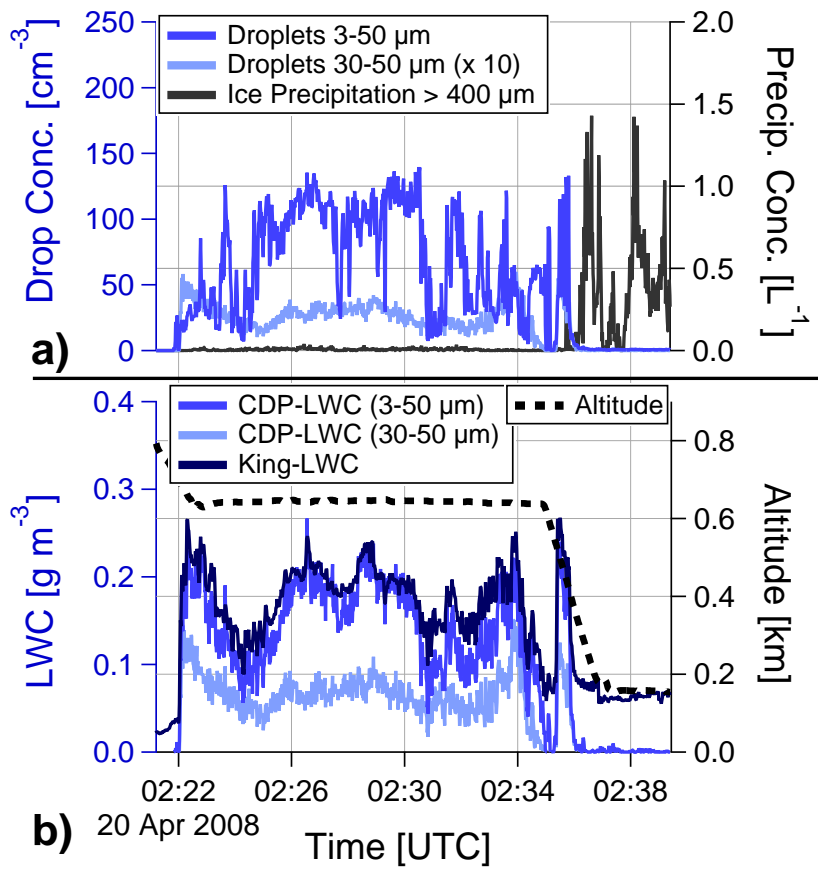

Fig. 5. (a) Timeseries of droplet and ice precipitation concentrations for clouds sampled during the clean case. Also shown are concentrations of large droplets $(30-50 \mu \mathrm{m})$ multiplied by a factor of 10 to aid visualization. (b) Timeseries of King-LWC and CDPLWC. Although only a very small fraction of the observed droplets are $>30 \mu \mathrm{m}$, these large drops often account for a major fraction of the observed LWC, as shown for this example.

The other important feature in our dataset is the negative correlation between $\mathrm{CO}$ and the concentration of precipitating ice particles. The clean case frequently contains ice concentrations in the range $0.1-1.0 \mathrm{~L}^{-1}$, whereas the warmpolluted and polluted cases almost never contain ice concentrations $>0.1 \mathrm{~L}^{-1}$, as shown by histograms of $1 \mathrm{~Hz}$ measurements of precipitation particles $>400 \mu \mathrm{m}$ (Fig. 6c). Figure $6 \mathrm{~d}$ shows average concentrations of ice precipitation as a function of temperature for these cases, and shows that a large difference is observed when comparing clean and polluted clouds in the same temperature range $\left(-10\right.$ to $\left.-14^{\circ} \mathrm{C}\right)$. For the warm-polluted case, the highest ice precipitation concentrations are observed in the temperature range -4 to $-5^{\circ} \mathrm{C}$. This may be a result of the Hallett-Mossop ice multiplication process, which occurs in the temperature range -3 to $-8^{\circ} \mathrm{C}$ when droplets collide with ice crystals and shatter upon freezing. However, even for this special subset of conditions, with riming occuring within a specific temperature range, ice precipitation concentrations are much lower than typically observed in the clean case.

\section{Discussion}

\subsection{Summary}

Biomass burning plumes, identified using in-situ trace gas measurements and back trajectory analysis, are highly correlated with enhanced $\mathrm{CCN}$ concentrations, as well as enhanced concentrations of aerosol particles that are typically thought to act as IN (e.g. biomass burning particles and large mineral dust particles). Microphysical observations show differences between polluted and clean clouds that persist regardless of condensed water content or cloud-top temperature. Clean clouds, identified from lower $\mathrm{CO}$ mixing ratios, exhibit broader droplet size distributions, more than 10 times greater concentrations of precipitating ice particles and more than 10 times greater ice water content than polluted clouds. Even though the minimum temperature in the polluted case is colder than that in the clean case, ice concentrations remain 1-2 orders of magnitude lower, in spite of greater dust and $\mathrm{BC}$ concentrations. These observations contradict the glaciation indirect effect proposed by Lohmann (2002), where ice concentrations are directly controlled by IN concentrations. Since the glaciation indirect effect was specifically formulated based on black carbon acting as contact nuclei from both anthropogenic and biomass burning sources, one would expect to see this effect given the conditions encountered during ARCPAC. Instead, our observations are consistent with classifications by Rangno and Hobbs (2001), who wrote regarding Arctic mixed-phase clouds:

"The picture that emerges is consistent with that which we have described previously for low- and middle-level stratiform clouds in temperate latitudes, namely that the amount of ice issuing from such clouds (slightly to moderately supercooled, i.e. -4 to $-20^{\circ} \mathrm{C}$ ) is strongly dependent on the largest cloud droplets generated in the cloud."

Our observations suggest that, while IN clearly must be present for ice to form in these clouds, IN concentrations are not the primary limiting factor for ice formation. Rather, ice formation appears to be more strongly dependent on the properties of the liquid droplet size distribution.

\subsection{Further considerations}

There are a number of important details to keep in mind when considering our conclusions. (1) A limited duration of incloud sampling was obtained. Because mixed-phase clouds are thermodynamically unstable, evolution of the cloud system is expected over time (Korolev and Isaac, 2003), but our observations are limited to brief time periods in a given cloud system. Sampling in the polluted case was particularly limited, since only one pass through the cloud was attained. However, for the clean and warm-polluted cases, cloud microphysical properties apparently remained stable for at least half an hour (Fig. 1b). Furthermore, the ice concentrations for the polluted and warm-polluted cases are consistent with 

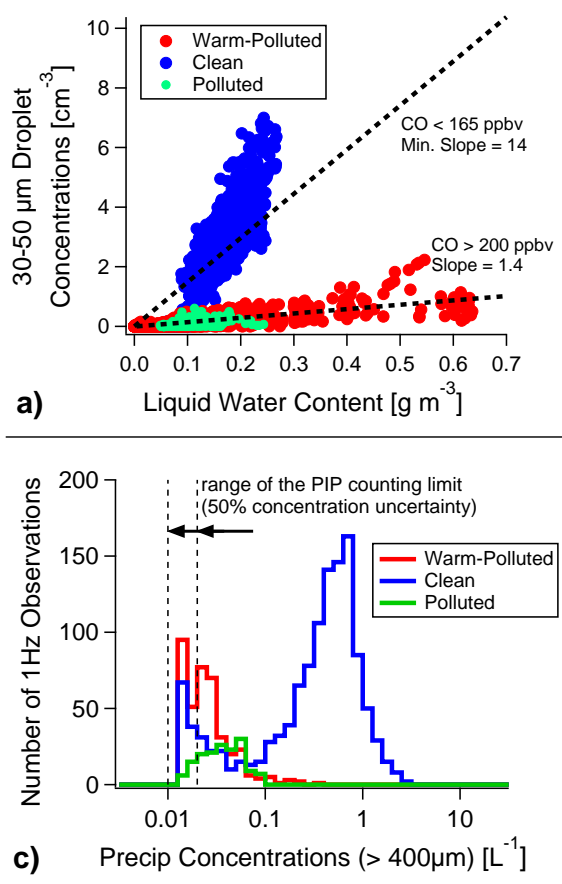
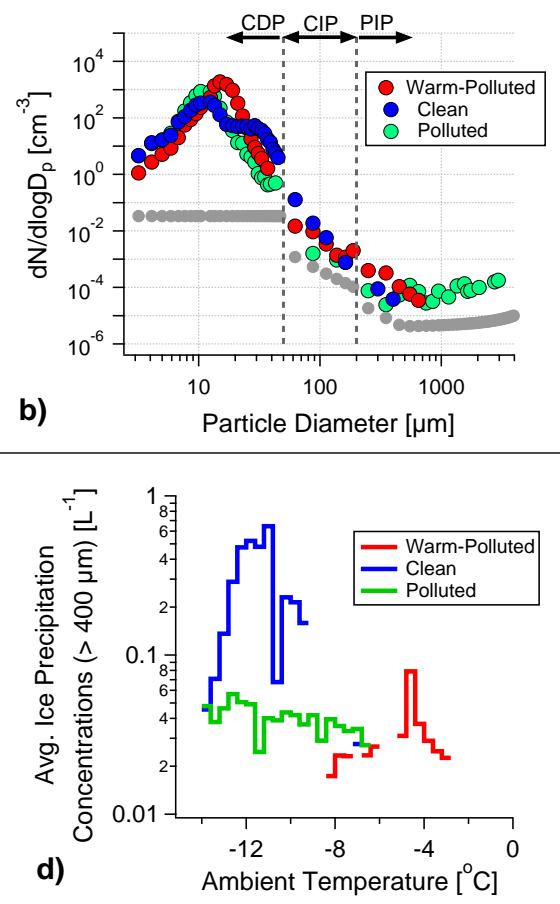

Fig. 6. Observations of cloud microphysical properties for the three different cases on the 19 April 2008 flight. (a) Number concentrations of large droplets $(30-50 \mu \mathrm{m})$ as a function of LWC. (b) Examples of measured $1 \mathrm{~Hz}$ cloud particle size distributions at cloud top. The minimum concentration observable by each instrument is denoted by grey markers. (c) Frequency distributions of $1 \mathrm{~Hz}$ ice precipitation number concentrations (on a log scale). (d) Average ice crystal number concentrations as a function of local ambient temperature (not necessarily the temperature at which the ice formed).

each other, in spite of meteorological differences between the cases and possible differences in age of the cloud systems, suggesting that the observations are robust. (2) The observed correlations do not directly reveal the mechanism by which droplet size impacts ice formation. Modeling studies have shown that large droplets and ice crystals can grow simultaneously by condensation/deposition at the expense of smaller droplets, since the evaporating droplets "must rise over the maximum of their Kohler curves" leading to a slight liquid supersaturation (Lebo et al., 2008); droplets can grow to as large as $50 \mu \mathrm{m}$ in diameter solely by vapor diffusion in these simulations. This too would result in a positive correlation between ice and large drop concentrations. However, it is unclear how the assumptions upon which these box model and parcel model results are based affect the validity of their results. For instance, the models do not allow ice precipitation to fall out of the liquid cloud layer. Since this assumption is markedly different from the observations, more work should be done to quantify how this assumption influences the modeling results. (3) We assume that high $\mathrm{CO}$ mixing ratios indicate more IN during cloud formation. Although the concentration of BC-containing particles, large particles, biomass burning particles and dust particles are greater in the polluted airmasses, mixing-state and other compositional differences between the polluted and clean cases could potentially result in fewer IN than expected. For example, it is possible that organic coatings on mineral dust particles can inhibit a large fraction of potential IN in the polluted cases, resulting in fewer IN overall. However, if our basic assumption is incorrect, and instead there are actually more IN in the clean cases, the question still remains: what is the source of IN in the clean Arctic boundary layer and how can high IN concentrations be maintained in the presence of steady precipitation? (4) We assume that secondary ice formation mechanisms do not dominate the observed ice concentrations. Three secondary ice formation mechanisms have been established (Pruppacher and Klett, 2000) related to: (a) freezing of riming droplets in the temperature range -3 to $-8^{\circ} \mathrm{C}$, (b) mechanical fracture of fragile ice crystals formed at temperatures -12 to $-16^{\circ} \mathrm{C}$, and (c) freezing of free-falling droplets. First, the clean clouds are outside the temperature range for the Hallet-Mossop mechanism. Second, since the clean and polluted clouds have the same cloudtop temperature, the dendritic ice crystals of similar size observed in both cases should be subject to the same degree of mechanical fracturing. Third, although larger droplets, as observed in the clean case, are expected to shatter upon freezing more often than small drops, “... shattering and splintering of freezing drops freely falling in the atmosphere results in an ice multiplication factor which at times surpasses a value of 
2 but rarely, if ever, exceeds a value of 10" (Pruppacher and Klett, 2000). Known ice multiplication mechanisms, therefore, are apparently insufficient to explain the observed difference in ice concentrations, which is often greater than a factor of 10 .

\subsection{Ice nucleation mechanisms}

While it appears that large droplets support ice formation, it is not entirely clear what ice nucleation mechanisms could be responsible for this correlation.

In the case of immersion freezing, smaller droplets may freeze less effectively since increased solute concentrations lower the freezing point temperature (de Boer et al., 2010). However, when droplets are greater than $\sim 10 \mu \mathrm{m}$ in diameter, a condition that is very often met at cloud-top in Arctic mixed-phase stratus (Rangno and Hobbs, 2001; Lawson et al., 2001; Korolev et al., 2003; McFarquhar et al., 2007), solute concentrations are typically too low $\left(<10^{-3} \mathrm{~mol} \mathrm{~L}^{-1}\right)$ (Diehl et al., 2006) to significantly inhibit immersion freezing (Pruppacher and Klett, 2000). If there is a surface enhanced nucleation rate (Djikaev et al., 2002; Shaw et al., 2005; Durant and Shaw, 2005), large droplets may be more likely to freeze if internal circulations that develop within the drop (Pruppacher and Beard, 1970) promote contact between immersed IN and the drop surface. It may be possible that the collision coalescence process also promotes this type of freezing mechanism.

Since contact nucleation has been shown in the laboratory to occur at warmer temperatures than does immersion freezing (Young, 1974; Cooper, 1974), contact freezing may play an important role in these slightly to moderately supercooled clouds. Diehl et al. (2006) showed that the collision efficiency between submicron aerosol particles and droplets (including Brownian motions but not phoretic effects) increases with droplet size, which could enhance ice formation via contact freezing where large droplets are present. Unfortunately, contact nucleation is the least understood of any freezing mechanism. For instance, it is unclear to what degree particles must be dry to act as contact nuclei (Pruppacher and Klett, 2000) and how such particles could remain dry within the same environment as supercooled droplets. If the contact nuclei must be dry, it is also unclear then why contact nucleation from the inside appears to act in a similar fashion, with freezing temperatures $3-5^{\circ} \mathrm{C}$ greater than that for which the same particle is immersed in the droplet (Durant and Shaw, 2005; Shaw et al., 2005). Furthermore, diffusio-, thermo- and electro-phoretic effects resulting from growing or evaporating droplets can substantially alter the droplet size dependent collision efficiency in complex ways (Young, 1974), which also need to be considered.

There is no reason we know of to expect ice nucleation by the deposition or condensation freezing mechanisms to be correlated with droplet size. In agreement with de Boer et al. (2011), our observations suggest that liquid-dependent ice nucleation modes are dominant.

\section{Conclusions}

This study provides compelling evidence that $\mathrm{CCN}$ are important for modulating ice processes in mixed-phase clouds, through impacts on the droplet size distribution. We have shown that measurements of gas phase tracers like CO that persist in cloudy environments are useful for identifying polluted clouds. However, more observations are needed to further constrain the specific mechanisms responsible for observed differences in cloud microphysical properties. Further work must be done to characterize ambient IN and to distinguish between ice nucleation modes. Reliable cloud microphysical measurements in the 50-400 $\mu \mathrm{m}$ size range, and the ability to distinguish between liquid droplets and ice particles in this size range, are needed for accurately capturing the initiation of ambient ice formation. Specifically, ice shattering artifacts need to be prevented. Better constraints on the evolving cloud dynamics (e.g. updraft velocity and cloud radiative properties), humidity and ice crystal growth rates are also needed for accurately modeling the highly sensitive processes taking place in Arctic mixed-phase clouds.

\section{Supplementary material related to this article is available online at: http://www.atmos-chem-phys.net/11/8003/2011/ acp-11-8003-2011-supplement.pdf.}

Acknowledgements. All authors acknowledge support from the NOAA climate and air quality programs. We thank Jorge Delgado and the NOAA Aircraft Operations Center for allowing use of their equipment and for technical support in the field. S. Lance thanks the US National Research Council for a research associateships program postdoctoral fellowship. A. Nenes acknowledges support from a US NSF CAREER grant. R. Moore acknowledges support from a US DOE global change education program graduate research fellowship. M. Shupe acknowledges support by US DOE grant DE-FG01-05ER63965. J. F. Burhart and A. Stohl were supported by the Norwegian Research Council in the framework of POLARCAT-Norway. MODIS hotspot data provided courtesy of NASA and the University of Maryland.

Edited by: P. Monks

\section{Disclaimer}

US government work not protected by US copyright laws. The use of trade, firm, or corporation names in this publication is for the information and convenience of the reader. Such use does not imply an official endorsement or approval by the University of Colorado, the United States Department of Commerce or the National Oceanic and Atmospheric Administration of any product or service to the exclusion of others that may be suitable. 


\section{References}

Albrecht, B. A.: Aerosols, cloud microphysics, and fractional cloudiness, Science, 245(4923), 1227-1230, 1989.

Bergeron, T.: On the physics of clouds and precipitation, Proc. Ve Assemblée Générale de l'Union Géodésique et Geophysique Internationale, Lisbon, Portugal, International Union of Geodesy and Geophysics, 156-180, 1935.

Borys, R. D., Lowenthal, D. H., Cohn, S. A., and Brown, W. O. J.: Mountaintop and radar measurements of anthropogenic aerosol effects on snow growth and snowfall rate, Geophys. Res. Lett., 30(10), 1538, doi:10.1029/2002GL016855, 2003.

Brock, C. A., Cozic, J., Bahreini, R., Froyd, K. D., Middlebrook, A. M., McComiskey, A., Brioude, J., Cooper, O. R., Stohl, A., Aikin, K. C., de Gouw, J. A., Fahey, D. W., Ferrare, R. A., Gao, R.-S., Gore, W., Holloway, J. S., Hübler, G., Jefferson, A., Lack, D. A., Lance, S., Moore, R. H., Murphy, D. M., Nenes, A., Novelli, P. C., Nowak, J. B., Ogren, J. A., Peischl, J., Pierce, R. B., Pilewskie, P., Quinn, P. K., Ryerson, T. B., Schmidt, K. S., Schwarz, J. P., Sodemann, H., Spackman, J. R., Stark, H., Thomson, D. S., Thornberry, T., Veres, P., Watts, L. A., Warneke, C., and Wollny, A. G.: Characteristics, sources, and transport of aerosols measured in spring 2008 during the aerosol, radiation, and cloud processes affecting Arctic climate (ARCPAC) project, Atmos. Chem. Phys. Discuss., 10, 27361-27434, doi:10.5194/acpd-10-27361-2010, 2010.

Cantrell, W. and Heymsfield, A.: Production of ice in tropospheric clouds, A Review, Bull. Amer. Meteor. Soc., 795-807, 2005.

Cober, S. G., Isaac, G. A., Korolev, A. V., and Strapp, J. W.: Assessing cloud-phase conditions, J. Appl. Met., 40, 1967-1983, 2001.

Cooper, W. A.: A possible mechanism for contact nucleation, J. Atmos. Sci., 31, 1832-1837, 1974.

Cozic, J., Mertes, S., Verheggen, B., Cziczo, D. J., Gallavardin, S. J., Walter, S., Baltensperger, U., and Weingartner, E.: Black carbon enrichment in atmospheric ice particle residuals observed in lower tropospheric mixed phase clouds, J. Geophys. Res., 113, D15209, doi:10.1029/2007JD009266, 2008.

Curry, J. A., Rossow, W. B., Randall, D., and Schramm, J. L.: Overview of Arctic cloud and radiation characteristics, J. Clim., 9, 1731-1764, 1996.

Cziczo, D. J., Froyd, K. D., Gallavardin, S. J., Möhler, O., Benz, S., Saathoff, H., and Murphy, D. M.: Deactivation of ice nuclei due to atmospherically relevant surface coatings, Environ. Res. Lett., 4, 044013, doi:10.1088/1748-9326/4/4/044013, 2009.

de Boer, G., Hashino, T., and Tripoli, G. J.: Ice nucleation through immersion freezing in mixed-phase stratiform clouds: Theory and numerical simulations, Atmos. Res., 96, 315-324, 2010.

de Boer, G., Morrison, H., Shupe, M. D., and Hildner, R.: Evidence of liquid dependent ice nucleation in high-latitude stratiform clouds from surface remote sensors, Geophys. Res. Lett., 38, L01803, doi:10.1029/2010GL046016, 2011.

DeMott, P. J., Prenni, A. J., Liu, X., Kreidenweis, S. M., Petters, M. D., Twohy, C. H., Richardson, M. S., Eidhammer, T., and Rogers, D. C.: Predicting global atmospheric ice nuclei distributions and their impacts on climate, Proc. Nat. Acad. Sci., 107(25), 1121711222, 2010.

Diehl, K., Simmel, M., and Wurzler, S.: Numerical sensitivity studies on the impact of aerosol properties and drop freezing modes on the glaciation, microphysics, and dynamics of clouds, J. Geo- phys. Res., 111, D07202, doi:10.1029/2005JD005884, 2006.

Djikaev, Y. S., Tabazadeh, A., Hamill, P., and Reiss, H.: Thermodynamic conditions for the surface-stimulated crystallization of atmospheric droplets, J. Phys. Chem. A, 106, 10247-10253, 2002.

Durant, A. J. and Shaw, R. A.: Evaporation freezing by contact nucleation inside-out, Geophys. Res. Lett., 32, L20814, doi:10.1029/2005GL024175, 2005.

Findeisen, W.: Kolloid-meteorologische vorgänge bei neiderschlags-bildung, Meteorologiche Zeitschrift, 55, 121-133, 1938.

Garrett, T. J., Radke, L. F., and Hobbs, P. V.: Aerosol effects on cloud emissivity and surface longwave heating in the Arctic, J. Atmos. Sci., 59, 769-778, 2002.

Garrett, T. J., Zhao, C., and Novelli, P. C.: Assessing the relative contributions of transport efficiency and scavenging to seasonal variability in Arctic aerosol, Tellus, 62B, 190-196, 2010.

Gorbunov, B., Baklanov, A., Kakutkina, N., Windsor, H. L., and Toumi, R.: Ice nucleation on soot particles, J. Aeros. Sci. 32, 199-215, 2001.

Gultepe, I. and Isaac, G. A.: Scale effects on averaging of cloud droplet and aerosol number concentrations: Observations and models, J. Climate, 12, 1268-1279, 1999.

Harrington, J. Y. and Olsson, P. Q.: A method for the parameterization of cloud optical properties in bulk and bin microphysical models, Implications for Arctic cloudy boundary layers, Atmos. Res., 57(1), 51-80, 2001.

Harrington, J. Y., Reisin, T., Cotton, W. R., and Kreidenweis, S. M.: Cloud resolving simulations of Arctic stratus - Part II: Transition-season clouds, Atmos. Res., 51(1), 45-75, 1999.

Hobbs, P. V. and Rangno, A. L.: Ice Particle Concentrations in Clouds, J. Atmos. Sci., 42(23), 2523-2549, 1985.

Hobbs, P. V. and Rangno, A. L.: Microstructures of low and middlelevel clouds over the Beaufort sea, Q. J. R. Meterol. Soc., 124, 2035-2071, 1998.

Intrieri, J. M., Shupe, M. D., Uttal, T., and McCarty, B. J.: An annual cycle of Arctic cloud characteristics observed by radar and lidar at SHEBA, J. Geophys. Res., 107, 8030, doi:10.1029/2000JC000423, 2002.

Jiang, H. L., Cotton, W. R., Pinto, J. O., Curry, J. A., and Weissbluth, M. J.: Cloud resolving simulations of mixed-phase Arctic stratus observed during BASE: Sensitivity to concentration of ice crystals and large-scale heat and moisture advection, J. Atmos. Sci., 57(13), 2105-2117, 2000.

King, W. D., Parkin, D. A., and Handsworth, R. J.: A hot-wire liquid water device having fully calculable response characteristics, J. Appl. Meteor., 1809-1813, 1978.

Korolev, A. V. and Isaac, G. A.: Phase transformation of mixedphase clouds, Q. J. R. Meteorol. Soc., 129, 19-38, 2003.

Korolev, A. V. and Mazin, I. P.: Supersaturation of water vapor in clouds, J. Atmos. Sci., 60, 2957-2974, 2003.

Korolev, A. V., Isaac, G. A., Cober, S. G., Strapp, W., and Hallett, J.: Microphysical characterization of mixed-phase clouds, Q. J. R. Meteorol. Soc., 129, 39-65, 2003.

Korolev, A. V., Emery, E. F., Strapp, J. W., Cober, S. G., Isaac, G. A., and Wasey, M.: Small ice particle observations in tropospheric clouds: fact or artifact? Airborne icing instrumentation evaluation experiment, Bull. Amer. Meteor. Soc., doi:10.1175/2010BAMS3141.1, in press, 2011. 
Lance, S., Medina, J., Smith, J. N., and Nenes, A.: Mapping the operation of the DMT continuous flow CCN counter, Aerosol Sci. Technol., 40(4), 242-254, 2006.

Lance, S., Brock, C. A., Rogers, D., and Gordon, J. A.: Water droplet calibration of a cloud droplet probe and in-flight performance in liquid, ice and mixed-phase clouds during ARCPAC, Atmos. Meas. Tech. Discuss., 3, 3133-3177, doi:10.5194/amtd3-3133-2010, 2010.

Lawson, R. P. and Baker, B. A.: Improvement in determination of ice water content from two-dimensional particle imagery, Pt. II: Applications to collected data, J. Appl. Meteor. Climat., 45, 1291-1303, 2006.

Lawson, R. P, Baker, B. A., Schmitt, C. G., and Jensen, T. L.: An overview of microphysical properties of Arctic clouds observed in May and July 1998 during FIRE ACE, J. Geophys. Res., 106(D14), 14989-15014, 2001.

Lebo, Z. J., Johnson, N. C., and Harrington, J. Y.: Radiative influences on ice crystal and droplet growth within mixed-phase stratus clouds, J. Geophys. Res., 113, D09203, doi:10.1029/2007JD009262, 2008.

Lohmann, U.: A glaciation indirect aerosol effect caused by soot aerosols, Geophys. Res. Lett., 29(4), 1052, doi:10.1029/2001GL014357, 2002.

Lohmann, U. and Feichter, J.: Global indirect aerosol effects: a review, Atmos. Chem. Phys., 5, 715-737, doi:10.5194/acp-5-7152005, 2005.

Lubin, D. and Vogelmann, A. M.: A climatologically significant aerosol longwave indirect effect in the Arctic, Nature Letters, 439(26), 453-456, 2006.

McFarquhar, G. M., Zhang, G., Poellot, M. R., Kok, G. L., McCoy, R., Tooman, T., Fridlind, A., and Heymsfield, A. J.: Ice properties of single-layer stratocumulus during the mixed-phase arctic cloud experiment: 1. Observations, J. Geophys. Res., 112, D24201, doi:10.1029/2007JD008633, 2007.

Mitchell, D. L., Zhang, R., and Pitter, R. L.: Mass-dimensional relationships for ice particles and the influence of riming on snowfall rates, J. Appl. Met., 29, 153-163, 1990.

Möhler, O., Benz, S., Saathoff, H., Schnaiter, M., Wagner, R., Schneider, J., Walter, S., Ebert, V., and Wagner, S.: The effect of organic coating on the heterogeneous ice nucleation efficiency of mineral dust aerosols, Environ. Res. Lett., 3, 025007 , doi:10.1088/1748-9326/3/2/025007, 2008.

Morrison, H., Shupe, M. D., Pinto, J. O., and Curry, J. A.: Possible roles of ice nucleation mode and ice nuclei depletion in the extended lifetime of Arctic mixed-phase clouds, Geophys. Res. Lett., 32, L18801, doi:10.1029/2005GL023614, 2005.

Mossop, S. C.: Secondary ice particle production during rime growth: The effect of drop size distribution and rimer velocity, Q. J. R. Meteorol. Soc., 111, 1113-1124, 1985.

Murphy, D. M., Cziczo, D. J., Froyd, K. D., Hudson, P. K., Matthew, B. M., Middlebrook, A. M., Peltier, R. E., Sullivan, A., Thomson, D. S., and Weber, R. J.: Single-particle mass spectrometry of tropospheric aerosol particles, J. Geophys. Res., 111, D23S32, doi:10.1029/2006JD007340, 2006.

NASA/University of Maryland. MODIS Hotspot/Active Fire Detections. Data set. MODIS Rapid Response Project, NASA/GSFC (producer), University of Maryland, Fire information for resource management system (distributors), available on-line at http://maps.geog.umd.edu/firms/, 2002.
Olivier, J. G. J. and Berdowski, J. J. M.: Global emission sources and sinks, A. A. Balkema, Brookfield, Vt., 2001.

Petters, M. D., Parsons, M. T., Prenni, A. J., DeMott, P. J., Kreidenweis, S. M., Carrico, C. M., Sullivan, A. P., McMeeking, G. R., Levin, E., Wold, C. E., Collett Jr., J. L., and Moosmüller, H.: Ice nuclei emissions from biomass burning, J. Geophys. Res., 114, D07209, doi:10.1029/2008JD011532, 2009.

Phillips, V. T. J., DeMott, P.J., and Andronache, C.: An empirical parameterization of heterogeneous ice nucleation for multiple chemical species of aerosol, J. Atmos. Sci., 65, 2757-2783, 2008.

Pinto, J. O.: Autumnal mixed-phase cloudy boundary layers in the Arctic. J. Atmos. Sci., 55, 2016-2038, 1998.

Pruppacher, H. R. and Beard. K. V.: A wind tunnel investigation of the internal circulation and shape of water drops falling at terminal velocity in air, Quart. J. R. Met. Soc., 96, 247-256, 1970.

Pruppacher, H. R. and Klett, J. D.: Microphysics of clouds and precipitation, 2nd Ed., Kluwer Academic Publishers, the Netherlands, 2000.

Quinn, P. K., Shaw, G., Andrews, E., Dutton, E. G., Ruoho-Airola, T., and Gong, S.: Arctic haze: Current trends and knowledge gaps, Tellus, 59B, 99-114, 2007.

Radke, L. F. and Hobbs, P. V.: Airborne observations of Arctic aerosols. III: Origins and effects of airmasses, Geophys. Res. Lett., 11(5), 401-404, 1984.

Rahn, K. A, Borys, R. D., and Shaw, G. E.: The Asian source of Arctic haze bands, Nature, 268, 713-715, 1977.

Rangno, A. L. and Hobbs, P. V.: Ice particles in stratiform clouds in the Arctic and possible mechanisms for the production of high ice concentrations, J. Geophys. Res., 106(D14), 15065-15075, 2001.

Reid, J. S., Hobbs, P. V., Ferek, R. J., Blake, D. R., Martins, J. V., Dunlap, M. R., and Liousse, C.: Physical, chemical and optical properties of regional hazes dominated by smoke in Brazil, J. Geophys. Res., 103(D24), 23059-32080, doi:10.1029/98JD00458, 1998.

Roberts, G. and Nenes, A.: A continuous-flow longitudinal thermalgradient CCN chamber for atmospheric measurements, Aeros. Sci. Tech., 39, 206-221, doi:10.1080/027868290913988, 2005.

Schwarz, J. P., Gao, R.-S., Fahey, D. W., Thomson, D. S., Watts, L. A., Wilson, J. C., Reeves, J. M., Darbehesti, M., Baumgardner, D. G., Kok, G. L., Chung, S. H., Schulz, M., Hendricks, J., Lauer, A., Kärcher, B., Slowik, J. G., Rosenlof, K. H., Thompson, R. L., Langford, A. O., Loewenstein, M., and Aikin, K. C.: Single-particle measurements of midlatitude black carbon and light-scattering aerosols from the boundary layer to the lower stratosphere, J. Geophys. Res., 111, D16207, doi:10.1029/2006JD007076, 2006.

Shaw, G. E.: Vertical distribution of tropospheric aerosols at Barrow, Alaska, Tellus, 27(1), 39-50, 1975.

Shaw, R. A., Durant, A. J., and Mi, Y.: Heterogeneous surface crystallization observed in undercooled water, J. Phys. Chem. Lett., 109, 9865-9868, 2005.

Shupe, M. D.: Clouds at Arctic atmospheric observatories, Part II: Thermodynamic phase characteristics, J. Appl Meteor. Clim., 50(3), 645-661, doi:10.1175/2010JAMC2467.1, 2011.

Shupe, M. D, Matrosov, S. Y., and Uttal, T.: Arctic mixed-phase cloud properties derived from surface-based sensors at SHEBA, J. Atmos. Sci., 63, 2, 697-711, 2006. 
Shupe, M. D., Walden, V. P., Eloranta, E., Uttal, T., Campbell, J. R., Starkweather, S. M., and Shiobara, M.: Clouds at Arctic atmospheric observatories, Part I: Occurrence and macrophysical properties, J. Appl. Meteor. Clim., 50(3), 626-644, doi:10.1175/2010JAMC2467.1, 2011.

Stohl, A., Forster, C., Frank, A., Seibert, P., and Wotawa, G.: Technical note: The Lagrangian particle dispersion model FLEXPART version 6.2, Atmos. Chem. Phys., 5, 2461-2474, doi:10.5194/acp-5-2461-2005, 2005.

Stohl, A., Berg, T., Burkhart, J. F., Fjæraa, A. M., Forster, C., Herber, A., Hov, Ø., Lunder, C., McMillan, W. W., Oltmans, S., Shiobara, M., Simpson, D., Solberg, S., Stebel, K., Ström, J., Tørseth, K., Treffeisen, R., Virkkunen, K., and Yttri, K. E.: Arctic smoke record high air pollution levels in the European Arctic due to agricultural fires in Eastern Europe in spring 2006, Atmos. Chem. Phys., 7, 511-534, doi:10.5194/acp-7-511-2007, 2007.

Twomey, S.: Pollution and the planetary albedo, Atmos. Environ., 8, 1251-1256, 1974.

von Blohn, N., Mitra, S. K., Diehl, K., and Borrmann, S.: The ice nucleating ability of pollen Part III: New laboratory studies in immersion and contact freezing modes including more pollen types, Atmos. Res., 78, 182-189, 2005.
Warneke, C., Bahreini, R., Brioude, J., Brock, C. A., de Gouw, J. A., Fahey, D. W., Froyd, K. D., Holloway, J. S., Middlebrook, A., Miller, L., Montzka, S., Murphy, D. M., Peischl, J., Ryerson, T. B., Schwarz. J. P., Spackman, J. R., and Veres, P.: Biomass burning in Siberia and Kazakhstan as an important source for haze over the Alaskan Arctic in April 2008, Geophys. Res. Lett., 36, L02813, doi:10.1029/2008GL036194, 2009.

Warneke, C., Froyd, K. D., Brioude, J., Bahreini, R., Brock, C. A., Cozic, J., de Gouw, J. A., Fahey, D. W., Ferrare, R., Holloway, J. S., Middlebrook, A. M., Miller, L., Montzka, S., Schwarz, J. P., Sodemann, H., Spackman, J. R., and Stohl, A.: An important contribution to springtime Arctic aerosol from biomass burning in Russia, Geophys. Res. Lett., 37, L01801, doi:10.1029/2009GL041816, 2010.

Wegener, A.: Thermodynamik der atmosphäre (in German), Leipzig, Poland, 1911.

Young, K. C.: The role of contact nucleation in ice phase initiation, J. Atmos. Sci., 31, 768-776, 1974. 